\title{
Bioavailability of Silica on Paddy Soils with Various Land Aging in Musi Rawas South Sumatera of Indonesia
}

\author{
Jon. Bimasri ${ }^{1,2, *}$, Dedi Budianta ${ }^{3 \cdot}$, Marsi $^{3}$, and Umar Harun $^{3}$ \\ ${ }^{1} \mathrm{Ph} . D$. Student Environmental Science Program of Universitas Sriwijaya, Indonesia \\ ${ }^{2}$ Agriculture Faculty, University of Musi Rawas South Sumatera, Indonesia \\ ${ }^{3}$ Posy Graduate Studies of Environmental Sciences of Universitas Sriwijaya, Indonesia
}

\begin{abstract}
Utilization of intensive paddy soils for rice cultivation are main causing deficiency of soil silica $(\mathrm{Si})$ due to high concentration $\mathrm{Si}$ adsorption in soils with values varies between 230 up to $470 \mathrm{~kg} \mathrm{ha}^{-1}$. The soil silica availability on agriculture lands in Indonesia varies from 203 to $982 \mathrm{mg} \mathrm{kg}^{-1}$, and the paddy soils in Java and Sumatra have shown a decreasing the silica between $11 \%$ to $20 \%$ in the last three decades, resulting in declining paddy soils productivity. This study was aimed to investigate the availability of silica in the paddy soils distributed in Musi Rawas. The study was scheduled from May to November 2016 using survey methods, and soil analyzes performed in laboratory of SEAMEO Biotrop Bogor.The results showed that availability of silica in wetland has reduced by $50 \%$ in two decades, and meanwhile the availability of silica in irrigated soils about 7.5 times lower compared to rainfed soils. The silica availability of irrigated soils from wetland had 4.5 times higher than the irrigated soils of dryland. Furthermore, silica contained in rice husk had also decreased down to $74.5 \%$, resulting in the decreasing of grain production due to a decrease in availability of silica in soil.
\end{abstract}

\section{Introduction}

Paddy soils called Sawah in Indonesia is a primary producing rice about 51.2 million tons per year with an average 4.7 tons ha- 1 or $95 \%$ of total grain production in Indonesia (Central Bureau of Statistic, 2014). The utilization of intensive paddy soils for rice cultivation has resulted the deficiency of silica[1]. The lack of silica is caused by the monoton rice cultivation between two to three times a year, causing in depletion of silica in soils[2]. Paddy crops absorb Si in high concentration ranged from 230 to 470 kgha-1[3].

Silica content in paddy soils in Java and Sumatera have decreased it from $11 \%$ to $20 \%$ over the last three decades[4]. While the available of silica on agricultural lands in Indonesia vary between 203 to $983 \mathrm{mgkg}-1[5,6]$. If soils contained less than $300 \mathrm{mg} \mathrm{kg}-1$ of silica is indicated the soils that has been critical of silica[7].

* Corresponding author: jbimasri@yahoo.co.id 
The returning of silica to paddy soils is required to maintain the sustainability of rice production because paddy rice requires silica exceeding nitrogen[5,6,8] and show two timesgreater than nitrogen needs [8,9]. Therefore, [10] reported that giving silica is necessary to improve the growth and yield of rice.

Silica or silicon dioxide $\left(\mathrm{SiO}_{2}\right)$ is a chemical compound formed from silicon and oxygen atoms which are the products of polymerization of silicic acid which can be forming as crystalline or amorphous[11] .

Silicon (Si) is a beneficial element which is useful for Gramineae crops. Silica is the second largest element in the crust of earth (27.7\%)[4]. The silica content of mineral soils is about $50 \%$, however the availability to the plants showed very low level[12]. The availability of silica in paddy rice is not positively correlated with the total amount of silica in the soil[ $[8,9,13]$.

The high silica in paddy soils can increase the oxygen content around the roots of rice[8,14]. The increasing of oxygen can oxidize methane to carbon dioxide $\left(\mathrm{CO}_{2}\right)$ resulting ini reducing the methane emissions to atmosphere[8]. The availability of silica in the soil is also able to increase the soil $\mathrm{pH}$ and improve the ability of plant to absorb the nutrients $[8$, 15]. Silica in a rice can also stimulate photosynthesis and translocation of $\mathrm{CO}_{2}$. The element also reduces abiotic stresses such as temperature, light radiation, the wind, and drought, as well as the increasing plant resistance to stresses such as disease and pest attacks[4,16]

\section{Materials and Methods}

This study was subjected to investigate the silica availability in soil, husk, and water using survey methods and laboratory analysis. The research had been conducted from May to November 2016 in Musi Rawas Regency, South Sumatera of Indonesia. The stratified random sampling was selected to determine the sample concerned. The sample was elaborated by 282 respondents who come from 14 sub-regency in Musi Rawas regency and divided in five groups i.e. 1) 1-20 years, 2) 21-40 years, 3) 41-60 years, 4) 61-80 years, and 5) more than 80 years

Total content of silica and dissolved silica were analyzed using gravimetry and nitric acid extraction, respectively with Atomic Absorption Spectroscopy as the further analysis. The silica content in irrigation water and husk were also determined using spectrophotometer and gravimetry, respectively.

\section{Results and Discussions}

Musi Rawas Regency has an area of approximately 636.717 ha distributed in 14 districts. About 30.511 ha is catagorized as a wetland, but only 20.158 ha or $66 \%$ of the wetland are paddy fild[17,18. The other land are used for non-rice and the remaining are undeveloped or bare soils.

In general, soil is formed by weathering process of rocks and minerals that produce soil particles with sizes vary from rough as sand, and smooth as clay[19]. In edaphology, soil serves as a venue for supporting the development of root growth of plants as well as water, air supply needs[16,20], and nutrient supplies[21].

One of soil physical properties that affect the content and availability of silica is soil texture. Texture is a relative comparison between sand, dust, and clay influencing the ability of soil to retain water[22]. The Paddy soil textures in Musi Rawas Regency are shown in Table 1. 
Table 1. Soil Particles Distribution on Sampling Depth Paddy Soils

\begin{tabular}{|c|c|c|c|c|c|}
\hline \multirow{2}{*}{$\begin{array}{l}\text { Type of } \\
\text { paddy } \\
\text { soils }\end{array}$} & \multirow{2}{*}{$\begin{array}{r}\text { Land } \\
\text { age } \\
\text { (year) }\end{array}$} & \multicolumn{3}{|c|}{$\begin{array}{c}\text { Soil Particles } \\
\text { Distribution } \\
\text { (\%) }\end{array}$} & \multirow[t]{2}{*}{$\begin{array}{l}\text { Texture } \\
\text { (USDA) }\end{array}$} \\
\hline & & Sand & Silt & Clay & \\
\hline \multirow{5}{*}{$\begin{array}{l}\text { Irrigated } \\
\text { dryland }\end{array}$} & $1-20$ & 66.61 & 25.30 & 8.09 & Sandy clay \\
\hline & $\begin{array}{c}21- \\
40\end{array}$ & 58.88 & 32.86 & 8.26 & Sandy clay \\
\hline & $\begin{array}{c}41- \\
60\end{array}$ & 32.72 & 18.87 & 48.41 & Argillaceous clay \\
\hline & $\begin{array}{l}61- \\
80\end{array}$ & 69.20 & 22.14 & 8.66 & Sandy Clay \\
\hline & $>81$ & 49.43 & 36.97 & 13.60 & Clay \\
\hline \multicolumn{2}{|l|}{ Average } & 55.37 & 27.23 & 17.40 & Sandy Clay \\
\hline \multirow{5}{*}{$\begin{array}{l}\text { Irrigated } \\
\text { wetland }\end{array}$} & $1-20$ & 28.96 & 33.69 & 37.35 & Argillaceous clay \\
\hline & $\begin{array}{c}21- \\
40\end{array}$ & 74.41 & 17.77 & 7.82 & Clayey sand \\
\hline & $\begin{array}{c}41- \\
60\end{array}$ & 83.87 & 8.58 & 7.55 & Clayey sand \\
\hline & $\begin{array}{l}61- \\
80\end{array}$ & 31.62 & 32.30 & 36.08 & Argillaceous clay \\
\hline & $>81$ & 74.76 & 17.53 & 7.71 & Sandy clay \\
\hline \multicolumn{2}{|c|}{ Average } & 58.72 & 21.97 & 19.31 & Sandy Argillaceous clay \\
\hline \multirow{5}{*}{$\begin{array}{c}\text { Rainfed } \\
\text { land }\end{array}$} & $1-20$ & 44.28 & 21.32 & 34.40 & Argillaceous clayey sand \\
\hline & $\begin{array}{l}21- \\
40\end{array}$ & 31.44 & 31.25 & 37.31 & Sandy Clay \\
\hline & $\begin{array}{c}41- \\
60\end{array}$ & 48.34 & 41.29 & 10.37 & Clay \\
\hline & $\begin{array}{l}61- \\
80\end{array}$ & 46.91 & 25.93 & 27.16 & Argillaceous clayey sand \\
\hline & $>81$ & 60.80 & 31.33 & 7.87 & Sandy clay \\
\hline \multicolumn{2}{|c|}{ Average } & 46.35 & 30.22 & 23.43 & Clay \\
\hline
\end{tabular}

The irrigated paddy soil contained higher sand in soil texture compared to Rainfed soil The sand percentage of irrigated soil from dryland is $55.37 \%$ and irrrigated paddy wetland is $58.72 \%$ while the rainfed field showed only $46.35 \%$. Table 2 showed that the differences of the sand contents have affected the total contents of silica that showed $29.2 \%$ and 24.9 $\%$ for irrigated and rainfed field, respectively. The silica content in sandy soil was between 450 to $480 \mathrm{~g} \mathrm{~kg}-1[23]$. The higher sand contents in soil influenced the silica content of soil due to the higher mineral quartz contained silica as the main compounds $[15,24]$.

The irrigated paddy soils originating from dryland has a sandy clay texture, while the irrigated soils of wetland textured as the Sandy Argillaceous clay. The soil dominated by the sand fraction showed less fertile compared silt fraction, because the sand was dominated by quartz mineral which was resistant to weathering process $[5,20]$ 
Table 2. Silica content on Paddy soils

\begin{tabular}{|c|c|c|c|c|}
\hline \multirow{2}{*}{$\begin{array}{c}\text { Land } \\
\text { age } \\
\text { (year) }\end{array}$} & \multicolumn{4}{|c|}{ Paddy soils } \\
\cline { 2 - 5 } & TCS (\%) & $\begin{array}{c}\text { Irrigated } \\
\left(\mathbf{m g k g}^{-1}\right)\end{array}$ & TCS (\%) & $\begin{array}{c}\mathbf{A S} \\
\mathbf{( m g ~ k g}^{-\mathbf{1}} \mathbf{)}\end{array}$ \\
\hline $1-20$ & 27.8 & $313.0(\mathrm{H})$ & 22.8 & $\begin{array}{c}1,676.9 \\
(\mathrm{H})\end{array}$ \\
\hline $21-40$ & 34.0 & $48.6(\mathrm{~L})$ & 31.6 & $629.0(\mathrm{H})$ \\
\hline $41-60$ & 22.6 & $41.6(\mathrm{~L})$ & 20.2 & $462.4(\mathrm{H})$ \\
\hline $61-80$ & 30.0 & $9.8(\mathrm{~L})$ & 21.5 & $397.1(\mathrm{H})$ \\
\hline$>80$ & 31.6 & $7.7(\mathrm{~L})$ & 28.8 & $10.5(\mathrm{~L})$ \\
\hline Average & 29.2 & $84.1(\mathrm{~L})$ & 24.9 & $635.2(\mathrm{H})$ \\
\hline
\end{tabular}

$\mathrm{TCS}=$ Total contents of silica; AS = Available of silica; $\mathrm{L}=$ Low; $\mathrm{H}=$ High

Table 3. Total content and available of silica on irrigated Paddy Soils

\begin{tabular}{|c|c|c|c|c|}
\hline \multirow{2}{*}{$\begin{array}{c}\text { Land } \\
\text { age } \\
\text { (year) }\end{array}$} & \multicolumn{4}{|c|}{ Type of paddy soils } \\
\cline { 2 - 5 } & \multicolumn{2}{|c|}{ Dryland } & \multicolumn{2}{c|}{ Wetland } \\
\cline { 2 - 5 } & TCS (\%) & $\begin{array}{c}\mathbf{A S} \\
\left(\mathbf{m g ~ k g}^{-\mathbf{1}}\right)\end{array}$ & $\begin{array}{c}\text { TCS } \\
(\mathbf{\%})\end{array}$ & $\begin{array}{c}\mathbf{A S} \\
\left(\mathbf{m g ~ k g}^{-\mathbf{1}}\right)\end{array}$ \\
\hline $1-20$ & 37.9 & $122.0(\mathrm{~L})$ & 17.6 & $503.9(\mathrm{H})$ \\
\hline $21-40$ & 31.2 & $11.3(\mathrm{~L})$ & 36.6 & $85.9(\mathrm{~L})$ \\
\hline $41-60$ & 24.9 & $7.8(\mathrm{~L})$ & 20.2 & $75.4(\mathrm{~L})$ \\
\hline $61-80$ & 25.4 & $7.5(\mathrm{~L})$ & 34.6 & $12.0(\mathrm{~L})$ \\
\hline$>80$ & 36.4 & $4.1(\mathrm{~L})$ & 26.7 & $11.2(\mathrm{~L})$ \\
\hline Average & 31.2 & $30.5(\mathrm{~L})$ & 27.1 & $137.7(\mathrm{~L})$ \\
\hline
\end{tabular}

TCS $=$ Total contents of silica; $\mathrm{AS}=$ Available of silica; $\mathrm{L}=$ Low; $\mathrm{H}=\mathrm{High}$

Table 4. Silica Availabity on Paddy Soils

\begin{tabular}{|c|c|c|}
\hline \multirow{2}{*}{$\begin{array}{c}\text { Land age } \\
\text { (year) }\end{array}$} & \multicolumn{2}{|c|}{ Paddy Soils } \\
\cline { 2 - 3 } & $\begin{array}{c}\text { Irrigated } \\
\text { (\%) }\end{array}$ & $\begin{array}{c}\text { Rainfed } \\
\text { (\%) }\end{array}$ \\
\hline $1-20$ & 84.5 & 62.5 \\
\hline $20-40$ & 14.4 & 26.5 \\
\hline $40-60$ & 76.4 & 14.1 \\
\hline $60-80$ & 21.4 & 97.4 \\
\hline Average & 49.2 & 48.9 \\
\hline
\end{tabular}

Table 5. Silica contents on irrigation water $\left(\mathrm{mgl}^{-1}\right)$

\begin{tabular}{|c|c|c|}
\hline \multirow{2}{*}{$\begin{array}{c}\text { Land age } \\
\text { (year) }\end{array}$} & \multicolumn{2}{|c|}{ Type of paddy soils } \\
\cline { 2 - 3 } & Dryland & Wetland \\
\hline $1-20$ & 3.5 & 2.4 \\
\hline $21-40$ & 3.6 & 2.5 \\
\hline $41-60$ & 3.1 & 3.3 \\
\hline $61-80$ & 1.8 & 2.3 \\
\hline$>80$ & 4.3 & 3.5 \\
\hline Average & 3.3 & 2.8 \\
\hline
\end{tabular}


Table 6. Silica content on rice husk (\%)

\begin{tabular}{|c|c|c|c|}
\hline $\begin{array}{c}\text { Land age } \\
\text { (year) }\end{array}$ & $\begin{array}{l}\text { Irrigated } \\
\text { dryland }\end{array}$ & $\begin{array}{c}\text { Irrigated } \\
\text { wetland }\end{array}$ & $\begin{array}{c}\text { Rainfed } \\
\text { wetland }\end{array}$ \\
\hline $1-20$ & 78.0 & 79.1 & 77.2 \\
\hline $21-40$ & 66.1 & 68.0 & 79.9 \\
\hline $41-60$ & 78.0 & 84.1 & 69.4 \\
\hline $61-80$ & 79.1 & 75.2 & 64.4 \\
\hline$>80$ & 74.3 & 76.4 & 67.8 \\
\hline Average & 75.1 & 76.6 & 71.7 \\
\hline
\end{tabular}

While the silt came from mineral feldspar and mica which are quickly broken down by the weathering. The weathering of minerals in rock will be releasing a variety of nutrient so that the silt-textured soils are more fertile than sandy soils. Sandy soils generally produce a single loose and granular structure resulting in poor water holding capability and sensitive to nutrient leaching[6,20].

The rainfed land has clay texture with an average content of clay as $23.43 \%$, and total content of silica showed lower content compared to irrigated land. Table 3 showed the total content of silica on rainfed amounting to $24.9 \%$ while the irrigated land originated from dryland and wetland amounted to $31.2 \%$ and $27.1 \%$ respectively. The low total content of soil silica is caused by the low sand content of soil.

The low total content of silica is not positively correlated to the available silica. The Rainfed paddy soils has high available of silica with value of $635.2 \mathrm{mgkg}-1$. The content of soil $\mathrm{Si}$ are 7.5 times higher than the contents of available silica in the irrigated soils that showed only $84.1 \mathrm{mgkg}-1$. The high available of silica was caused by the mineral quartz contained in the sand. Most of the mineral have been degraded and release silica into the soil. The high available silica is also influenced by the lower dewatering of silica because of the intensity of the planting is performed only once a year.

Soil silica content is divided into total and dissolved silica. Table 2 represented the analysis of availability content of silica in paddy land which distinguished by the land age.

Table 3 exhibits the total content and available of silica in the irrigated soils. The total content of silica of the irrigated land and rainfed lands are $29.2 \%$ and $24.9 \%$, respectively. The high amount of total silica content of irrigated land is affected by the different type and levels of mineral soil constituent and mineral weathering in soil.

The total amount of silica present in the irrigated soil of dry land showed a higher percentage which is $31.2 \%$ compared to the wetlands that showed a percentage of $27.1 \%$. Nizuma explained that the silica content of soil is varied ranging from 5 to $40 \%$ [23]. In clay soil has the silica content ranging from 200 to $320 \mathrm{~g} \mathrm{~kg}-1$ whereas in sandy soil showed the higher silica content of between 450 to $480 \mathrm{~g} \mathrm{~kg}-1$. Haynes explained that the silica content of mineral soil showed the high level of silica about 50\%[12]. Furthermore, the availability of silica for plants was low. The content of silica in soil was determined by several factors such as mineral content, land development level, soil temperature, and the ability of soil to retain water[25-27].

The availability of silica in Paddy soils are not positively correlated to the total content of silica in soil $[8,28])$. The amount of silica available in the irrigated paddy soil derived from dryland 4.5 times lower than the irrigated fields of wetlands at various levels of the land aging. The average amount of silica available on the wetland irrigated paddy soil is 137.7 mgkg- 1 of soil, whereas the dryland irrigated paddy soils is $30.5 \mathrm{mgkg}-1$. The available silica contents in the wetland irrigated paddy soils at the beginning of the land opening are high with value of $503.9 \mathrm{mg} \mathrm{kg}-1$ of soil. 
Table 4 showed the silica availability in paddy soils tends to decrease with the increasing of land aging. Describe by[2] that the soils which were planted with rice plants continuously for a long time causing the decreasing of silica availability. The decreasing of silica was caused by the rice plant which absorbs a lot of silica. The high absorption of silica was not followed by the adding the silica in soil, so silica becomes depleted. According to the Soil Research Institute, the available of silica in Indonesia, especially in Java and Sumatera, have significantly decreased as $11 \%$ to $20 \%$ in the last three decades[4,29].

The main source of silica in soil is derived from the rock mineral and biological materials [22] and dissolved in the soil as the primary and secondary mineral[12]. The amount of silica which is absorbed by the paddy showed two times greater than nitrogen[9,30]. The intensive utilization of paddy soils for rice cultivation has exhibited the silica deficiency in the soil.

The Silica availability in crust of earth present in an amount high enough that 27.7\%[4]. The silica content in the mineral soils approximately $50 \%$, but the availability of silica for plants still show the low level[12]. Soils in the tropical county like Indonesia have faced the intense weathering, thus losing the high content of silica.

The amount of silica available on the rainfed land was high at each level of land age. The silica available keeps positively grown up by the increasing the land age whereas the irrigated land shows the low content of silica, i.e. $92.4 \mathrm{mgkg}-1$. The high amount of the silica available on the rainfed land was caused by low intensity of cultivation in a year, so that the silica which transported by the harvest is relatively small. [31]reported that the silica available in the tropical area are low due to desilication process. Furthermore, the silica available are also influenced by the distribution of mineral rock, climate, and land management[30].

The production of dry grain harvest which produced by the rice plants cultivated on the irrigated land is higher than the production in the rainfed land in all land aging. The average amount of grain production which produced on the irrigated soils about 4.0 tons ha-1, where as in the rainfed can only produce the dry grain harvest an average of 3.4 tons ha- 1 . The rice production of rainfed land was relatively low, i.e. between 2.0 to 3.5 tons ha- 1 . The low grain production which cultivated on the rainfed land was caused by the low soil $\mathrm{pH}$, organic $\mathrm{C}$ and $\mathrm{N}[16,32]$, although the high amount of nutrient such as $\mathrm{Mg}, \mathrm{Fe}$, and $\mathrm{Cu}$.

The land aging can affect to increase the grain production. The irrigated rice production with the land age of 50 years to over 80 years showed the decreasing of rice production. Table 4 presents the decreasing percentages of available silica in the paddy soils. The decreasing of the rice production was caused by the decreasing of available silica. The decreasing of available silica was begun since the opening of land and continue to decrease as the increasing of land age. the decreasing was caused by the paddy plant which absorbs $\mathrm{Si}$ quite a lot. Paddy plant can absorb silica between 230 to $470 \mathrm{~kg}$ ha-1[3]. More over, the decreasing of silica available can be accelerating by the intensive cultivation which continuously planting as 2 or 3 times a year[2,33].

The average decreasing of silica available in Paddy soils in Musi Rawas as 50\% in the last two decades. The available silica in the rainfed soils showed the high level in the first opening of land. Despite the silica available content decrease as the increasing of land age, the level of silica available in the rainfed still possess the higher content compared to the irrigated field. The high amount of silica available and the slow decline of the silica available in the rainfed soil was caused by the amount of silica which transported by the rice plant in harvest was low because the land was cultivated only once a year. The high amount of silica available in rainfed is not correlated to the grain production. The low 
production was caused by the limiting factor on the rainfed land which has the physical and chemical properties of soil which does not support the grain production.

The irrigation water also contains silica which can be a source of silica to paddy soils that uses the irrigation water for plant growth. The analysis of water irrigation of silica is presented in Table 5.

The silica content in irrigation water that comes into paddy soil in dryland showed as $3.3 \mathrm{mg}$ liter-1, which higher than the silica content in the irrigation water which comes into wetland paddy soil, i.e. $2.8 \mathrm{mg}$ liter-1. The amount of silica in the irrigation water coming into paddy soils is much lower than the silica contained in irrigation water that is on the secondary channel that has not passed through paddy field, i.e. $10.1 \mathrm{mg}$ liter-1.

The water requirement for paddy plant reached $1.3 \mathrm{~m} 3$ ton-1 of grain, of which $48 \%$ comes from ground water and surface water, $44 \%$ comes from rain water[34]. The Irrigation water for agriculture contains Silica with high enough quantities so that it can affect the availability of Silica in the soil. The silica content in the irrigation water that comes into the irrigated land with an average of $3.0 \mathrm{mg}$ liter-1. Silica content derived from the irrigation water is input to supply silica in rice plants. In natural silicate source for the rice crop comes from the irrigation water and the result of weathering of soil and plant debris [30,35].

The rice husk is a waste in the processing of grain. The husk of the rice plant biomass has the high silica content compared to the most other parts of rice biomass[8,36]. The silica content in each husk which produced by the plant is presented in Table 6 .

The number of husks resulting from the cultivation of rice plants is high because the grain is composed of 16.3 to $28 \%$ husk. Rice husk or skin is the outer portion of the grain containing silica that has the highest silica among the rice crop biomass [37].

The Silica content of rice husk from paddy soils produced an average of $74.5 \%$. The total silica content of the rice husk from paddy soil indicates a high rate because the rice plants absorb silica in appreciable amounts [9,37]. The amount of silica in the husk produced from irrigated rice is higher than the silica content of husk generated from rainfed. The low silica content in the husk produced from rainfed land as the lands of rainfed not get silica from water supply for irrigation. In addition, the difference in silica content contained in husks depending on the status of availability of silica in the soil[1,39].

\section{Conclusion}

The silica content in irrigated land, rainfed, irrigation water and husk are about $84.1 \mathrm{mg}$ $\mathrm{kg}^{-1}, 635.2 \mathrm{mg} \mathrm{kg}^{-1}, 3.0 \mathrm{mg}$ liter-1, and $74.5 \%$, respectively. The amount of silica available in the irrigated soils showed 7.5 times lower compared to rainfed soil. The Silica availability of the irrigated soils of wetland showed 4.5 times higher than the irrigated soils of dry land. The silica availability of wetland is reduced on average by $50 \%$ in the last two decades. The decreasing of wetland productivity was caused by the decreasing of availability of soil silica.

\section{References}

1. Thilagan K, Mohanty S, Shahid M, Tripathi R, Nayak AK, Kumar. Popular Kheti. 2, 1 (2014)

2. Darmawan, KyumaK,Saleh A, Subagyo H, Masunaga T, Wakatsuki T. Soil Science and Plant Nutrition 57 ( 2006)

3. CasmanKG, Peng S, Doberman. Soil Sci Plant Nutr 43 (1997) 
4. Soil Research Institute Knowing Silica as Nutrient. 32, 3 (2010)

5. Husnain.The availability of silica (Si) in the rice soil and determination methods of silica available in the land and comparison of some extraction methods (Soil Research Centre, Bogor, 2009)

6. Husnain, Wakatsuki T, Setyorini D, Hermansah, Sato K, Masunaga T. Soil Science and Plant Nutrition 54 (2008)

7. Sumida H. Agric Exp Stn 85 (1992)

8. Koyama S, Katagiri T, Minamikawa K, Kato M, Hayashi H. JARQ 50, 4 (2016)

9. Savant NK, Snyder GH. Plant Anal 28 (1997)

10. YasariE, Yazdpoor H, Kolhar HP, Mobasser HR. International Journal of Biology 4, 4 (2012)

11. Sulastri S, Kristianingrum S Various compounds Silica; Synthesis, Characterization and Utilization. Proceedings of the National Seminar on Research, Education and Application of Mathematics. Faculty of Science, University of Yogjakarta. Yogjakarta. pp 211-216. (Indonesian) (2010)

12. Haynes RJ. J. Plant Nutrition and Soil Science 17, 6 (2014)

13. Klotzbucher T, Marxen A, Jahn R, Vetterlein D Silicon cycle in rice paddy fields: insights provided by relations between silicon forms in topsoils and plant silicon uptake. (NutrCycl Agroecosyst, Springer Science+Business Media Dordrech, 2016)

14. Dubey AK. Asian Journal of Multi diplinary Studies 2, 10 (2014)

15. Yohana O, Hanum H, Supriadi. Agroecotechnology 1, 4 (2013)

16. Borah D, Ghosh M, Ghosh DC, Gohain T. Agric Res 5, 3 (2016)

17. Musi Rawas, Regional Planning Agency Musi Rawas in Figures (Muara Beliti, 2015)

18. Department of Food and Crops and Horticulture of Musi Rawas. Wetland Broad Standard in Musi Rawas (2016)

19. Hasibuan BE. Fundamentals of Soil Science (Universitas Sumatera Utara Press, Medan, 2008)

20. Hardjowigeno, S. Soil Science (Akademika Pressindo, Jakarta, 2007)

21. Budianta, D., Wiralaga, AYA and Lestari W. J. Trop. Soils 15, 2 (2010)

22. Djajadi. J. Littri 14, 3 (2008)

23. NizumaS, Kubo S, Morikuni H. Effect of Silica Gel Application on Growth and Silicon Contents of Rice Seedling in Nursery Bed with Different Available Silicon Contents. Proceedings of Silicon in Agriculture. Yamagata Japan (II) (2002)

24. Kraska JE, Breitenbeck GA. Agronomy Journal 102, 2 (2010)

25. Huang LY, Li HX, Zhang XM, Lu WS, Liu YJ. Pedosphere 16, 5 (2006)

26. Sommer M, Kaczorec D, Kuzyakov Y, Breuer J. J. Plant Nutr. Soil Sci 169 (2006)

27. Ali MA, Sattar MA, Islam MN, Inubushi K. Integrated effects of organic, inorganic and biological amendments on methane emission, soil quality and rice productivity in irrigated paddy ecosystem of Bangladesh: field study of two consecutive rice growing seasons. (Plant Soil, Springer, 2014)

28. Tubana BS, Babu T, Datnoff LE. Soil Science 181, 9 (2016)

29. Research and Development Centre for Food Crops Rice and Silicon, Brief Information of food crops knowledge bank of indonesia (Research and Development Centre for Food Crops, Ministry of Agriculture of Indonesia, 2010)

30. Bocharnikova EA, Loginov SV, Matychenkov VV, and Storozhenko PA Russian Agricultural Sciences 36, 6 (2012)

31. Husnain, Rochayati S, Adam I, Silica nutrient management on agricultural land in Indonesia (IAARD, Soil Research Institute, Bogor, 2011) 
32. Sujana I.P., Suryana I.M., Suryasdipura I.N.L. Improvements physical and chemical properties rainfed rice soil biochar through granting land in efforts to increase productivity, (Agrimeta, 2013)

33. Ahmad A, Afzal M, Ahmad AUH, Tahir M. Cercetări Agronomiceîn Moldova 46, 3 (2013)

34. Chapagain AK, Hoekstra AY The Blue, Green and grey water footprint of rice from production and consumption perspectives. (Elsevier, The Netherlands, 2010)

35. Gascho G.J. Silicon sources for agriculture indatnoff le, snyder gh, and korndorfer gh (eds) (Silicon in Agriculture, Elsevier Science Amsterdam, The Netherlands, 2001)

36. Luh, B.S. Van Nostrand Reinhold. USA 2 (1991)

37. Ashtiani FA, Kadir J, Nasehi A, Rahaghi S.R.H, Sajili H. J. Trop. Agric. Sci 35 (2016)

38. Marxen A, Klotzbücher T, Jahn R, Kaiser K, Nguyen VS, Schmidt A, Schädler M, Vetterlein D, Interaction between silicon cycling and straw decompositionin a silicon deficient rice production system. Plant Soil. (Springer International Publishing Switzerland, 2015) 